Relations industrielles

Industrial Relations

\title{
Behavioural Determinants of Public Sector Illegal Strikes
}

Cases from Canada and the U.S.

Déterminants behavioraux des grèves illégales dans le secteur public

\section{Determinantes del comportamiento en las huelgas ilegales del sector publico}

\section{Casos en los Estados Unidos y Canadá}

\section{Robert Hebdon}

Volume 53, numéro 4, automne 1998

URI : https://id.erudit.org/iderudit/005285ar

DOI : https://doi.org/10.7202/005285ar

Aller au sommaire du numéro

Éditeur(s)

Département des relations industrielles de l'Université Laval

ISSN

0034-379X (imprimé)

1703-8138 (numérique)

Découvrir la revue

Citer cet article

Hebdon, R. (1998). Behavioural Determinants of Public Sector Illegal Strikes: Cases from Canada and the U.S. Relations industrielles / Industrial Relations, 53(4), 667-690. https://doi.org/10.7202/005285ar

Tous droits réservés @ Département des relations industrielles de l'Université Laval, 1998
Ce document est protégé par la loi sur le droit d'auteur. L'utilisation des services d'Érudit (y compris la reproduction) est assujettie à sa politique d'utilisation que vous pouvez consulter en ligne.

https://apropos.erudit.org/fr/usagers/politique-dutilisation/ 


\title{
Behavioural Determinants of Public Sector Illegal Strikes
}

\section{Cases from Canada and the U.S. ${ }^{1}$}

\author{
ROBERT HEBDON \\ New York State's School of Industrial and Labor Relations, Cornell University, \\ Ithaca, New York.
}

This article develops a framework for analyzing illegal public sector strikes that explains observed patterns of behaviour of employees, unions, managers, and third parties. It is found that no-strike laws diminish such positive effects of right-to-strike bargaining systems as eliciting information, adjusting expectations, and providing catharsis. A new theoretical outline helps understand and explain such illegal strike characteristics as the suddenness of strike development, the rank-and-file nature, lack of union control, conflict without clearly defined union objectives, and breakdown of the conflict regulation process by neutral agencies. Three policy issues emerge: some conflict could have been avoided with a broader scope of bargaining (PATCO and Ontario jail guards); mandatory and more responsive third party procedures should be legislatively provided; and such information about worker discontent as grievance usage should be made available to dispute settlement agencies and mediators before conflict escalates out of control.

Taking away the right to strike is a bit like eliminating the vapor safety valve on a boiler. Employees need to know that they have this means of relieving their frustrations and internal tension - even if they never use it. Otherwise an explosion is inevitable

(Cooke 1983: 99).

1. The author acknowledges the valuable research assistance of Jean-Paul Alexandrowicz. 
The purpose of this paper is to identify and analyze certain common behavioural characteristics of North American illegal public sector strikes. These strikes are important because they occur in significant numbers, often have devastatingly negative effects, and represent a complete dysfunction of the strike avoidance policy mandate - a central goal of many public sector collective bargaining systems.

U.S. strike data for the period 1983-1994 for major strikes of over 1000 employees, reveals only slightly higher mean strike rates ${ }^{2}$ (7.7 percent) in states where public sector workers have the right to strike compared to states where strikes are banned (5.3 percent) (Hebdon 1996). In addition, 34 out of 78 major strikes (43.6 percent) were illegal.

The effects of these illegal strikes can be severe. They can cause irreparable harm to the public, the collective bargaining parties, and unions. The strike of the Professional Air Traffic Controllers Organization (PATCO) in 1981 provides a stark example, involving a serious threat to the safety of air travel, the firing of thousands of controllers, and the decertification of the union.

The continued occurrence of these illegal strikes is virtually guaranteed by the multitude of laws banning strikes by public employees. In Canada, five provinces grant the right to strike to most public employees (Swan 1985; Goldenberg 1988; Gunderson and Hyatt 1996). ${ }^{3}$ But all provinces and states restrict the right to strike for some occupations. In the U.S., for example, no less than 38 states prohibit strikes for public sector employees. Only twelve states have legalized public sector strikes and in four others the courts have granted the right to strike to some employees (Kearney 1992: 282-6; Lund and Maranto 1996). ${ }^{4}$ In almost all U.S. and Canadian jurisdictions, therefore, the public sector "illegal strike" is a inevitable element of these industrial relations systems. Most illegal strikes in the U.S. occur in states that have collective bargaining laws but where the strikes are supposed to be replaced by mediation, fact-finding, some form of interest arbitration, or a combination of these dispute mechanisms. The fewest illegal strikes result where interest arbitration is a substitute for strikes (Stern and Olson 1982).

These strikes can attract national attention by placing vital services in jeopardy and threatening public safety and health. They can invoke

2. Here strike rates are calculated by dividing total state strikes by the number of public sector unionized employees in that state.

3. A recent example is Ontario, where the right to strike was extended to all employees of the Crown on January 1, 1994.

4. But even in these 12 right-to-strike states many public sector employees in essential services cannot legally strike. 
extraordinary interventionist measures by governments, including injunctions, the use of the national guard or other law enforcement agencies, and such heavy penalties on strikers and unions as fines, jail sentences, dismissals and union decertification. For example, in the U.S., the military was used 45 times between 1970 and 1981 to replace striking public sector workers (Jacobs 1982). No less important than their negative impact on law and order is the irreparable damage to the relationship between the bargaining parties.

In this paper, an industrial relations framework will be developed for analyzing these walkouts that will help to explain observed patterns of behaviour of employees, unions, managers and third parties. The nostrike laws will be seen to diminish such positive effects of the right to strike as eliciting information, adjusting expectations, and providing catharsis. A theoretical outline will emerge that takes into account the impact of the removal of the legal right to strike on the collective bargaining process. The adjusted theory will help understand and explain such illegal strike characteristics as the suddenness of strike development, the rank-and-file nature and corresponding lack of union control, conflict without clearly defined union objectives, and breakdown of the conflict regulation process by neutral agencies.

While the findings in this paper are relevant for the on-going policy debate about the right to strike in the public sector, it is not the primary focus. The purpose of this paper is twofold. First, by examining common patterns in new and previous case studies, a theoretical framework will be developed for analyzing illegal strikes. Second, the paper will begin a discussion of policies designed to avoid illegal strikes or at least minimize some of their more extreme effects.

The paper is in three parts. The first part considers some theoretical implications for the collective bargaining process of the removal of the legal right to strike. In the light of the framework developed in this first part, the next part examines certain characteristics of two illegal strikes of jail guards in Ontario in 1979 and 1989. The last part applies this expanded theory to two past illegal strikes, summarizes the major findings of the paper, and concludes with a discussion of some policy implications.

\section{THEORY REVIEW}

There is a prodigious academic literature describing and analyzing the causes and effects of public sector strikes - both legal and illegal. Historians, legal scholars, economists, sociologists, psychologists, and industrial relations researchers have all made major contributions toward our 
understanding of these events. However, because each field or discipline has approached strikes from their own theoretical perspective, there is no common framework of analysis. Moreover, there is little evidence of any attempt to link up case studies (even within disciplines) to establish patterns of behaviour. It is as if each strike was an independent event, unrelated in any way to similar events in the past. While it is certainly true that each case has unique features, certain behavioural patterns can be observed.

Examples of this strike literature include the U.S. air traffic controllers in 1981 (Northrup 1984, 1986; Hurd and Kriesky 1986; Meltzer and Sunstein 1983; Kearney 1992: 306), numerous North American illegal postal strikes (Kearney 1992: 274; Goldenberg 1983: 91; Cooke 1983; Sombretto 1983; Shannon 1978), transit strikes in New York city (Donovan 1990), and jail guard walkouts in New York state in 1979 (Zimmer and Jacobs 1981; Peterson 1981) and Ontario in 1979 and 1989 (Hebdon 1992); and an Ontario hospital strike in 1981 (White 1990). ${ }^{5}$

Banning the right to strike eliminates the positive role it plays in the regulation of conflict. Moreover, by suppressing conflict in the form of strikes, no-strike laws may have the unintended effect of redirecting industrial strife from strikes to other more costly forms (such as absenteeism, turnover, slowdowns, grievances, and pilfering) (Sapsford and Turnbull 1994; Hebdon and Stern 1998). When illegal strikes do occur, their intensity may be greater ${ }^{6}$ (Jamieson 1968; Woods 1968). The suddenness of these strikes and their illegality may render ineffective dispute settlement mechanisms such as mediation, fact-finding, and arbitration. None of the three industrial relations parties -- management, labour, and neutrals -may be able to influence events, for example, as tentative settlements are rejected by rank-and-file members.

Surveys of economic, behavioural, and collective voice theories of strikes include Wheeler (1985), Godard (1992), Card (1990), and Kervin (1988). Strike theories have in common the assumption that a legal strike is possible during the collective bargaining process. These models are almost always explicitly private-sector in character. Some researchers, however, have examined the impact of special characteristics of the public sector on strikes (e.g., multilateral bargaining, politics, and legal framework) (e.g., Kochan 1974). But there is no model that explains how or why strikes occur under no-strike laws.

5. For a review of some public sector strikes at the U.S. federal level, see Becker (1982); at state and local levels, see Sterret and Aboud (1982).

6. Intensity is defined to include such extreme effects as serious danger or harm to the public, fines, penalties, injunctions, and jail sentences. It is recognized that in terms of duration, illegal public sector strikes tend to be shorter than legal ones (Hebdon 1996). 
To understand the impact of no-strike laws on collective bargaining it is necessary to look at the role of the strike (or threat thereof) in collective bargaining systems where the right to strike exists. Gunderson, Kervin, and Reid (1983) list seven theoretical determinants of strikes: uncertainty, misinformation, credible threats, political factors, cathartic, internal, ${ }^{7}$ and relative joint costs and benefits. Of these factors, this paper singles out three for further consideration: misinformation, adjusting expectations (internal), and catharsis (see Kervin 1988; Gunderson 1988; and Woods 1968). It will be argued here that the absence of these right-to-strike properties under collective bargaining systems that ban strikes helps explain the parties' behaviour associated with illegal strikes. Thus, to understand the impact on collective bargaining under no-strike laws of the loss of each of these strike threat characteristics, each is examined in turn.

\section{Adjusting Expectations}

A common North American strike ban system is compulsory interest arbitration. A positive view of compulsory arbitration, originally advanced by Stevens (1966) and later refined by Farber and Katz (1979), is that a contract zone is possible due to the parties' differing expectations, uncertainty, or risk preferences about arbitrator behaviour in fashioning an arbitration award. A contract zone may be possible, for example, if unions have a greater aversion to risk than employers.

One problem with this theory is that the union, in the case of an arbitration, usually does not include the rank-and-file membership. Union members rarely vote on the decision to proceed to arbitration, do not attend the hearing, and do not ratify a final and binding arbitration award. ${ }^{8}$ Thus, the expectations, risk preferences, and attitudes to uncertainty may not only differ between the parties but also between the union leadership and its members.

No-strike laws may unintentionally destroy a vital collective bargaining bridge between the union leadership and its membership. ${ }^{9}$ The Stevens (1966) and Farber and Katz (1979) bilateral models may be viewed, therefore, as special cases where the union membership partici-

7. Included in this category is the process of adjusting expectations between the union leadership and rank-and-file members.

8. A hospital union in Ontario (SEIU) attempted to minimize the problem of lack of member participation in arbitration by holding the hearing in a hotel ballroom large enough to accommodate local presidents.

9. This bridge may be more difficult to maintain in large, geographically dispersed, more heterogeneous bargaining units (e.g., post office, state or provincial employees). Conversely, divergences between union leaders and members may be less likely in smaller more homogeneous units (e.g., fire and police). 
pates in the arbitration process and/or shares the union leadership's goals and preferences. This suggests the need for a more general, trilateral model of public sector collective bargaining that takes into account the complex relationship between the union and its membership. In the trilateral model, the threat of a strike forces the union to reconcile its own institutional and political objectives with both the objectives of the employer and the interests (often competing) of the rank-and-file. Remove the threat of a (legal) strike and this reconciliation process is weakened or destroyed. ${ }^{10}$

\section{Generating Information}

The strike potential also forces workers to order their priorities or preferences, thus providing valuable information to both parties. This information is more difficult to obtain without the right to strike because there is little cost associated with avoiding these tough decisions. Therefore, intraorganizational or internal bargaining, one of the essential processes of collective bargaining, may be impeded by the lack of strike potential (see Walton and McKersie 1965). The significance of this loss for the bargaining system cannot be overstated. In a system with the right to strike, "the resolution of [the parties'] internal trade-offs is as essential to the success of the industrial relations system as is the resolution of disputes between the parties" (Woods 1968: 96). For Finkleman (1974: 158), under the right to strike the union must make "hard-nosed compromises between the claims of conflicting groups in light of the risks involved," but "when the strike weapon is replaced by arbitration, there are no risks, or only minimal risks, involved in throwing every issue, no matter how insignificant it may be, into the lap of the arbitrator."

\section{Providing Catharsis}

Restricting strikes can also have negative effects on the nature of conflict itself. Jamieson (1968) predicts major explosions of conflict as hostility is allowed to build up. Suppressing the safety-valve or cathartic effect of the strike may lead to conflict volatility. According to social conflict theory, conflict regulation may be more difficult under rigid systems designed to suppress conflict. In this respect, Coser (1965) makes a useful distinction between types of social conflict. Conflict is realistic if it is a means to remedy some underlying cause and nonrealistic if it is an end in itself derived from a need for tension release (Coser 1965: 172). Nonrealis-

10. Ideally, the model in the public sector ought to include a fourth element - political divergence on the management side (see Katz and Kochan 1992 for a discussion of multilateral bargaining). 
tic conflict, more likely under rigid or restrictive collective bargaining systems, is harder to regulate or channel into less aggressive means because satisfaction is derived from the act itself. Thus, nonrealistic conflict may be a feature of collective bargaining systems that restrict the right to strike. This may be especially so if the conflict is over goals other than collective bargaining ones (e.g., PATCO's legislative goals).

In summary, collective bargaining without the right to strike may have serious unintended consequences. It may prevent the adjustment of expectations necessary for compromise; stifle valuable information on the preferences of the parties; lead to major explosions of pent-up pressures; and be more difficult to regulate due to the lack of clearly defined objectives. An examination of two Ontario jail guard strikes will illustrate some of these deficiencies. ${ }^{11}$

\section{STRIKES IN THE ONTARIO CORRECTIONAL SERVICES} 1979 AND 1989

In the fall of 1979, some 3,000 jail guards employed in sixty provincial jails across Ontario, went on an illegal strike to obtain their own bargaining category (Hebdon 1992). ${ }^{12}$ While the strike lasted only three days, it had profound consequences for the provincial government (the employer), the Ontario Public Service Employees Union (OPSEU), its membership, and the public. The President of OPSEU, Sean O'Flynn, was jailed for twenty-three days and the participating guards were all disciplined. Given the fact that it was the first strike in the Ontario Public Service since collective bargaining began in 1963, it attracted intense media attention and generated considerable public shock at the sudden collapse of the industrial relations system.

Ten years later in 1989, the jail guards again joined in a province-wide job action. This strike had at least one characteristic in common with its 1979 predecessor. Neither strike was fully anticipated by either the employer or the union. The 1989 strike, in particular, was initiated by the union's rank-and-file. These strikes raised serious questions about the stability of labour relations in the Ontario Public Service. ${ }^{13}$

11. The research for these cases is primarily based on extensive interviews with union and management officials as well as rank-and-file jail guards.

12. Appendices providing fuller descriptions of the two illegal jail guard strikes in Ontario in 1979 and 1989 are available on request from the author.

13. In fact, a review of the law in 1992 by the New Democratic Party (NDP) government cited this instability in providing for the right to strike for non-essential public service employees. These employees (including the jail guards) achieved the right to strike in 1994 and had their first strike in February of 1996. 


\section{The 1979 Strike}

To understand the strike issues, a brief historical sketch is necessary. The Ontario government took over the administration of municipal jails in 1968. Some jail guards, many of whom were in a rival municipal union, opposed the move for fear of losses in pay and benefits. For example, workers at the Toronto Don Jail went on strike in January 1968 to protest the terms of their transfer to the civil service. ${ }^{14}$ Jail guards from the transferring municipal sector were merged with guards in the reform institutions that were already part of the civil service. The combined group was given a guarantee by the Civil Service Association of Ontario (CSAO) (OPSEU's predecessor), that they would be able to vote on all wage offers. ${ }^{15}$ This promise was a critical factor in the 1979 strike.

The evolving structure of bargaining within the Ontario public service was also an important element in the strike. In 1968, for the purpose of bargaining on issues of a service-wide nature such as benefits, the 3,000 correctional employees were in a bargaining unit consisting of some 50,000 civil servants. For wage bargaining only, the 50,000 unit was divided into five occupational groupings. Thus, the 1968 "guarantee" was not entirely fulfilled because the 3,000 guards were lumped into a large operational category for wage bargaining consisting of some 20,000 employees. Technically the guards had the right to vote but, as a minority, had little practical influence on the outcome.

In 1975, OPSEU and provincial government representatives negotiated an expansion of the five wage-negotiation groupings to eight smaller ones. One such group, the Institutional Care and Correctional Services (ICCS) category, consisted of approximately 3,000 custodial classifications (including the jail guards) and some 6,000 other employees, most of whom were employed in psychiatric hospitals and centres for the developmentally handicapped. In spite of the move to a smaller category in 1975 , this group of 3,000 custodial workers still felt outnumbered and disadvantaged by the bargaining structure. They wanted the power to turn down a contract offer without being outvoted by some other group; in short, they wanted their own bargaining category.

Their anger and frustration was fuelled by the widening wage gap between jail guards and the first-class constable with the Ontario Provincial Police (OPP). For example, from 1969 to 1979, the gap had increased from $\$ 1,000$ to about $\$ 5,500$ per year. ${ }^{16}$ For the guards, the bargaining structure was only a means to an end; the real issue was economic. The

14. The Toronto Globe and Mail, January 17, 1968, p. 1.

15. CSAO NEWS, February, 1968.

16. OPSEU Brief to Arbitrator Prof. Harry Arthurs, December 1979. 
workers were further frustrated by the federal government's 1975-78 program of wage controls, which precluded any possibility of wage catch-up to the OPP officers through arbitration.

\section{Workplace Issues}

Against a background of a rigid, paramilitary management style typical of correctional institutions, the jail guards faced the increasing pressures brought on by inmate overcrowding, staff reductions and cut-backs of services, and a policy shift in various North American jurisdictions to more liberal approaches to inmate rights and rehabilitation. ${ }^{17}$

\section{Summary Comments on the 1979 Strike}

Several observations are important about this Ontario conflict, which the anti-strike legislation failed to contemplate and could not contain or control. The first is the rank-and-file nature of the strike commencing with the impromptu strike vote taken at the November 10 meeting of the correctional delegates. President O'Flynn's absence at this meeting underscores the unplanned nature of the action. Second, the speed with which the guards mobilized and prepared for possible strike action appeared to take the parties by surprise. The explosive nature of the strike also made it difficult for the regulatory agency to play a useful role. This regulatory vacuum was inadequately filled by the courts. Third, the strike was noteworthy for its intensity: the jailing of the union's president, the reprimand placed on the files of all workers, and the potential threat to the safety and security of the public. The damage to the parties and their bargaining relationship was profound. Both the union leadership and the employer seriously underestimated the gravity of the strike issue -- the creation of a separate bargaining category.

\section{Ten Years Later: The 1989 Conflict}

The 1989 conflict can be viewed as a continuation of the issues signalled in the 1979 strike. The major difference this time, of course, was the absence of conflict over the structural matter of a separate category for custodial workers. By 1989, the correctional category was well-established as a viable bargaining entity for wage negotiations. Once again, there was a coalescence of economic and workplace issues. Against a background of increasing militancy over wage negotiations culminating in an overwhelming rank-and-file rejection of a directly negotiated settlement rec-

17. Interestingly, enhanced inmate rights leading to a loss of status and authority on the part of the guards were identified by Zimmer and Jacobs (1981) as a cause of the 1979 strike of jail guards in New York state. 
ommended by the union, the two-sided problem of inmate overcrowding and under-staffing ignited local job actions.

To understand the 1989 conflict, it is necessary to define some new labour relations terms. A lock-out is used in the commonly accepted labour relations way; management acts to lock out employees. A lockdown is an action by the guards whereby inmates are indefinitely locked into their cells. A lock-in is an occupation of the institution by the guards where management is locked out. A lock-in may be accompanied by a lock-down.

\section{The Events of 1989}

In March, several union locals such as those at the Metro East and West Detention Centres, the Mimico Correctional Centre, and the Toronto (Don) Jail, held information pickets to protest the government's wage offer of 3 percent for a one-year contract. While these actions were taking place, on March 17 local conditions at the Oak Ridge Mental Health Centre for the criminally insane gave rise to a confrontation between local management and the union. The local union initiated a 24-hour lock-in over complaints about "working conditions, security, under-staffing and bad management" at the maximum security institution. ${ }^{18}$ After learning of the local job action, the union President, James Clancy, arrived at the institution and negotiated all night with Health Ministry officials to resolve the strike. An agreement was reached at 6.30 a.m. on March 18.

After rejecting the option of a province-wide illegal strike in April, the guards began a summer work-to-rule (slowdown) campaign across Ontario "to protest overcrowding and under-staffing, and to demand early retirement at full pension"19. The next blow-up occurred at the Toronto Jail. The local union claimed that 46 guards were needed to handle the inmate population which had swelled to 591 in an institution designed to hold 260 inmates. The government denied the union claim, saying that the jail could comfortably accommodate between 500 and 550 inmates. ${ }^{20}$ On August 8, 29 out of 32 guards on the day shift, 25 out of 28 on the afternoon shift, and all 28 on the night shift booked off sick to protest inmate overcrowding.

\section{The Conflict Boils Over}

In late September, 66 percent of the guards rejected a wage offer recommended by the union's provincial negotiating team. The wage offer

18. OPSEU NEWS, March 22, 1989.

19. OPSEU VOICES, February 1990. Note that pensions were not negotiable under the 1989 collective bargaining law.

20. Toronto Star, August 9, 1989, p. A6. 
would have fallen short of parity with the guards in federal institutions. The guards decided to give arbitration a chance and again rejected the illegal strike route. Over 100 guards participated in a lobby campaign at Queen's Park to try to convince the government of the need for more staff to handle the ever-increasing inmate population. Up to this point, a province-wide confrontation seemed unlikely and the union had made no plans for collective action.

A major province-wide job action was then triggered by an incident at the Hamilton-Wentworth Detention Centre. ${ }^{21}$ On October 21, two officers suffered mental breakdowns while attempting to control eighty prisoners transferred from Toronto. Guards responded by locking down these "Toronto wing" inmates. Negotiations with local management failed and the guards locked down the entire institution, bolstered by pickets from surrounding facilities. President James Clancy arrived in Hamilton but negotiations "founder on the demand to fill 19 guard vacancies and to disperse the Toronto prisoners to other wings to reduce tensions." By noon on October 23, "18 facilities are locked down, 9 are affected by mass sick leave book-offs, 3 are working to standing orders, and several more have picket lines." 22 By then, the union was actively encouraging locals to support the job actions by whatever means possible. At the Oak Ridge facility the local union locked down the inmates and locked out management (i.e., a lock-in). The conflict spread to other facilities. Also on October 23, the union charged the employer under the Occupational Health and Safety Act with increasing the inmate population "to the extent that the health and safety of workers has been placed in jeopardy".

On October 24, OPSEU claimed that job actions are taking place in 45 of the 51 correctional institutions (18 lock-downs, 13 sick-outs, 9 working to standing orders, and others picketed). As an example of the impact of the conflict at the local level, sixty-seven guards were suspended at the Metro West Detention Centre; pressure increased as untrained staff were called in to do the guards' work. On the same day, the Ontario Supreme Court issued an injunction declaring the OPSEU job actions illegal strikes under the Crown Employees Collective Bargaining Act. In response to the injunction, President Clancy declared in a press conference that it would be "impossible and irresponsible to comply with this injunction when the safety of our members, inmates, and the public is at stake". ${ }^{23}$ He called for negotiations on overcrowding and under-staffing of facilities, early retirement for correctional officers, and the safety of staff. At the HamiltonWentworth Centre, police entered the facility with a copy of the injunc-

21. OPSEU VOICES, February 1990.

22. Ibid.

23. Ibid. 
tion. Guards turned over their keys to police and joined the picket line outside. Management took over the institution and locked out the guards. This action was repeated at several other facilities.

On October 25, serious negotiations to break the deadlock finally commenced between the union and various government officials from the Ministry of Correctional Services, the Management Board of Cabinet, and the Office of the Premier. A settlement was reached after ten hours of negotiations with a signed agreement providing for further and immediate negotiations on "overcrowding and under-staffing, health and safety, and early retirement for correctional officers". ${ }^{24}$ On December 4 , as a result of these further negotiations, the Minister of Correctional Services, the Honourable Richard Patten, announced the construction of a 272-bed Centre in Milton, an extra 68 beds at the Mimico Correctional Centre, 115 new staff positions, and other steps to deal with health and safety problems in correctional facilities. Later, an arbitration award was handed down on the wage issue that provided for some measure of catch-up for the guards but fell short of their ultimate objective of achieving parity with the Ontario Provincial Police. ${ }^{25}$

\section{The Economic Issue}

In order to understand the economic concerns fuelling the anger of correctional officers, interest arbitration awards were examined to determine the role that the negotiation and arbitration processes played in establishing appropriate wage comparisons. ${ }^{26}$ From an analysis of these awards, no evidence was found that correctional officers had been illserved by the decisions of these arbitration boards. It is true that the correctional officers' goal of parity with the OPP was not achieved, but clearly their increases since 1979, absent the wage control year of 1983 , far exceeded the average for the rest of the public service.

Was the 1989 job action exclusively related to local working conditions and not wages? The answer may be found in the failure of collective bargaining under the no-strike law to force a reconciliation of employee, employer, and union expectations about what is possible or achievable. Arbitrators may have done their best to replicate the right-to-strike bargaining outcome and effect a reasonable compromise between competing union and management goals, but the arbitration procedure could not replicate the right-to-strike bargaining process.

24. Ibid.

25. The Toronto Globe and Mail, December 5, 1989.

26. The awards and settlements from 1979 (the first settlement of the new correctional services category), up to 1989, the year of the second job action are summarized in appendices that are available on request from the author. 
In bargaining with the right to strike, the rank-and-file objective of parity with the OPP would probably either be achieved or guard expectations would be adjusted. Compromise is the by-product of a costly process involving the potential of substantial losses by management, union, and workers. Most workers participate in this process by virtue of strike and ratification meetings and votes. Under no-strike laws, however, there are no strike votes or meetings and arbitration awards are not ratified. Thus, there is no process whereby the expectations of the parties can be tested and altered. It is difficult for either party to get a true reading of the depth of feeling on any given issue. Evidence of this was the rank-and-file repudiation of the settlement recommended by their elected union bargaining team and the persistence over the ten-year period of the wage issue in spite of reasonable attempts at compromise by various arbitrators.

\section{Summary Comments on the 1989 Strike}

There are several characteristics of the 1989 strike that parallel those of the strike ten years earlier. Both strikes were led by the union's rankand-file members and both developed quickly into province-wide job actions. This explosiveness is uncharacteristic of the measured conflict more typical of the Canadian industrial relations system with its emphasis on mandatory government intervention in the form of mediation and conciliation. The union objectives were also ill-defined and hastily crafted, reflecting the suddenness of the conflict and lack of union knowledge of employee preferences. The strikes illustrate the union leader's dilemma between obeying the law (interpreted by the members as a betrayal of their cause) or supporting the members (leading to severe penalties including jail) (see Gotbaum 1972).

The employer also faced a serious dilemma. It feared that flexibility on the issues in the face of an illegal strike threat would encourage more illegal actions in the future. On the other hand, a hard-line bargaining position might not have done anything to solve the underlying conditions causing the strike, thereby leading to more conflict. The government's response was almost identical in both strikes: resort to the court injunction with little or no positive effect in reducing tensions.

\section{CONCLUSION: AN EXPANDED FRAMEWORK}

This part summarizes the findings of the case studies and examines their implications for an expanded theoretical framework. The new theory outlined is used to revisit studies of two illegal public sector strikes. The paper concludes with a discussion of some public policy considerations. 


\section{Adjusting Expectations}

These Ontario strikes support the observation that interest arbitration, even when effectively replicating the right-to-strike outcome, cannot reproduce the process of adjusting expectations. No-strike laws produce less participatory forms of collective representation, especially when an impasse occurs in bargaining. ${ }^{27}$ They reduce the likelihood of the adjustment of expectations of the parties so necessary for compromise and effective negotiations and critical for labour relations stability. This deficiency applies equally to final-offer forms of interest arbitration, since the union's membership is not normally involved in any realigning of positions at arbitration. ${ }^{28}$

\section{Eliciting Information}

The confrontations were significant for the serious misreading of the depth of feeling of the guards by the employer and the union leadership. One of the reasons for the inability of the parties to measure the seriousness of the issues was the unavailability of the usual industrial relations yardstick - the right to strike. Given that the act of taking a strike vote is itself illegal, the union had no legal mechanism to measure the resolve of the guards on the issues and to order their preferences. It is concluded that a right-to-strike system would have generated more realistic (less destructive) conflict. ${ }^{29}$

Retrospectively, a strike over bargaining structure appears somewhat trivial when weighed against the risks and costs of the illegal strike. Because there was no orderly mechanism to provide a test of seriousness and resolve, both parties underestimated the importance of the strike issue to correctional officers. Even if the strike vote had been taken and all the negotiating skills of the parties had proved fruitless, legal strike procedures could have provided for a more regulated conflict environment with less potential damage to the relationship. Also, with an essential services agreement, there would be a reduced threat to the safety and security of the public. ${ }^{30}$

27. This is not meant to imply that unions are less democratic, but instead that the no-strike law can have a negative impact on worker participation through collective bargaining.

28. In the case of the jail guards, final-offer arbitration may have imposed reasonableness on the union leadership and bargaining team but there is no orderly process for this adjustment to be transmitted to the union rank and file save the strike vote.

29. Some argue that the right to strike might reduce strikes (see Kheel 1969). While the 1979 strike may well have been avoided under a right-to-strike law, it is not argued here that there will be fewer strikes as a result. Recent U.S. evidence on this was discussed above.

30. In fact, after obtaining the right to strike in 1994, a legal strike did occur in February of 1996 but with an agreement between the parties on essential services. 


\section{Providing Catharsis}

The strikes in correctional services provide examples of what Coser (1965) defined as nonrealistic conflict, which he predicted would be difficult to regulate because the action is taken for its own sake. Hence, there was the refusal of the offer of arbitration by the guards before the 1979 strike and the confused objectives of the 1989 actions. ${ }^{31}$

\section{The 1979 New York State Jail Guard Strike Revisited}

The strike of jail guards in New York state in 1979 was remarkably similar to its Ontario counterpart of the same year. Each one attracted national attention as the largest strike of jail guards in its country's history (see Zimmer and Jacobs 1981). Other common properties included: a complex combination of economic and workplace conditions as strike issues; rank-and-file motivation and lack of union control; unrealistic worker expectations; the cathartic nature of the action; and the failure of the normal collective bargaining institutions to effectively regulate the conflict. The major differences, on the other hand, were the length of the strike ( 3 days and 17 days for Ontario and New York respectively), the greater violence of the conflict and more massive government intervention (the use of National Guard) in New York (due, in part, to the length of the strike), and the racial overtones of the New York strike.

Zimmer and Jacobs (1981) conclude that collective bargaining failed to prevent the strike in New York because of certain inadequacies in the bargaining framework. They go further in contending that "the operation of collective bargaining in the New York correctional system aggravated the underlying organizational strains and thereby contributed to the 1979 strike" (1981: 535). The issues of control over inmates, status, and racial tensions (the strike causes), according to Zimmer and Jacobs (1981), were not appropriate for the bargaining table. Their analysis, however, includes no discussion of possible deficiencies in the Taylor Law in terms of limitations on the scope of negotiable issues or flaws in the bargaining process due to the legal strike ban.

The framework developed here provides an expanded interpretation of the events described by Zimmer and Jacobs. They found that the union leadership was to blame for failing to identify and articulate the issues appropriate for collective bargaining and for not reducing rank-and-file

31. Examples include the staffing and early retirement demands of the guards. Because they would require special legislation amending public service collective bargaining law, these proposals were inappropriate issues for the bargaining table. 
expectations (Zimmer and Jacobs 1981)..$^{32}$ But the framework developed in this paper suggests that these are inherent characteristics of collective bargaining under a no-strike law. The union has no effective mechanism to determine the real rank-and-file priorities or to reduce expectations under the Taylor Law. The cathartic nature of the conflict (producing unrealistic conflict) largely accounts for the difficulty of channelling it into more peaceful paths. In rejecting the wage offer, for example, one union official explained: "It was as if the members wanted to strike to show the department something; the details of the contract didn't matter a bit. The contract provided the time to strike, but underlying problems provided the enthusiasm" (Zimmer and Jacobs 1981: 538). Thus, if blame must be apportioned in this ugly confrontation, a significant amount must be directed to the inadequacies in the legal bargaining framework in terms of its inability to regulate conflict.

\section{PATCO 1981 Strike Revisited}

After the PATCO strike of 1981, there was a debate in the literature over the real strike issues. Northrup (1984) argued that the basic union objective was legislative in nature - to achieve "wage determination on a private sector model." Hurd and Kriesky (1986), on the other hand, asserted that the union's primary goals were to address such work-related problems as reducing the workweek, improving retirement conditions, and dealing with autocratic management (see also Northrup 1986). The fact of the debate itself is illustrative. The framework developed in this paper would lead one to a different conclusion about the true strike issues.

The lack of clearly defined objectives on the part of the air traffic controllers was a function of a collective bargaining system in which strikes are illegal. But given that the costs of striking were much greater than even in the private sector, why didn't the strike threat force realism on all sides? Several factors came into play here: the PATCO leadership was new and inexperienced; the illegality of strikes made for a secretive process of setting priorities; and, most importantly, based on past experience the PATCO members did not expect a strike. From 1968 to 1981 there were no less than six major job actions, most of which incurred only minor penalties (Northrup 1986). Thus the rank-and-file controllers did not expect penalties (costs) from striking, consequently their objectives were predictably vague and unrealistic (a union "wish list").

32. On p. 544 they state: "For its part, the union must identify the issues that can be brought into the collective bargaining system and articulate them coherently...Somehow the union must reduce worker expectations about what collective bargaining can accomplish." 
The conflict was also "unrealistic" in the Coser (1965) sense of the term. It reflected an underlying frustration with conditions; as a catharsis, it did not need a particular focus. Hurd and Kriesky (1984) identify several studies from 1970-78 that exposed the "hypertension, job stress, and burnout" caused, in part, by a "para-military, heavy handed style" of management. Like the jail guard strikes, these festering conditions at the workplace inevitably produce a need for an uncontrollable release of tension. Thus, this conflict without a clear purpose is difficult if not impossible to regulate. The picture created by Northrup (1984), of PATCO carrying out a top-down, carefully crafted strike plan to achieve private-sector labour relations is difficult to reconcile with the rank-and-file nature of all previous job actions as well as the 1981 strike. The PATCO fiasco, therefore, must be seen not only as the failure of a union to interpret political and economic events, but, more importantly perhaps, the devastating collapse of a flawed collective bargaining system.

\section{The Generalizability of the Framework}

Before turning to policy questions, it is necessary to comment on the applicability of the framework to all public sector illegal strikes. The question can legitimately be asked: are the four cases examined in this paper representative of all illegal strikes or are they extreme examples? This paper makes the theoretical case that no-strike laws inhibit some of the positive functions of collective bargaining where the right to strike exists in terms of eliciting information, ordering priorities, and providing catharsis. In theory, therefore, these are broad principles with universal application.

In practice, however, there will be numerous exceptions. One can imagine a jurisdiction, for example, where there is no formal right to strike but the parties act as if that right existed. ${ }^{33}$ The four cases in this study have been chosen because of the high-profile nature of each strike. These cases commanded significant public attention, were studied by scholars from several disciplines, and attracted the keen interest of policy-makers. As such, they were indeed extraordinary examples of illegal strikes. But the main differences between these strikes and more mundane examples are their magnitude and notoriety. The theoretical framework developed in this paper, therefore, would have broad application to most illegal public sector

33. Crisis bargaining in New York city in the 1970s may provide an example of this where several unions negotiated as if they had the right to strike and the city acted accordingly. This bargaining occurred in spite of the substitution of compulsory interest arbitration for the legal right to strike. 
strikes. Like any theoretical proposition, however, only further testing of it in a wide range of cases will establish the scope of its application.

\section{Policy Implications}

In the private sector, it is widely believed that the right to strike is necessary to provide greater balance of bargaining power between management and labour, thereby facilitating harmonious and peaceful relations. ${ }^{34}$ On the other hand, in the absence of a credible strike threat, "both sides are less likely to bargain in good faith; this in turn leads to unsatisfactory and acrimonious labour relations and ironically to more and longer strikes." ${ }^{35}$ In the context of New York's no-strike law (Taylor Act), Kheel (1969) predicted that a legal strike threat would prevent strikes by improving the bargaining process and the skill of the negotiators to prevent strikes.

The question of the impact of the legal right to strike on the frequency, duration and size of public sector strikes is an empirical one lying beyond the scope of this paper. However, this study does provide support for the proposition that conflict generated by a public sector illegal strike is often more intense than under a more regulated industrial relations environment. There is a high probability that the catastrophic events surrounding the cases examined in this paper would have been avoided if collective bargaining had been permitted to function under a legal right to strike. A necessary condition for the threat of a strike to perform its proper function is that there be an orderly process for determining essential services. If, on the other hand, essential services become such a high proportion of the membership that an effective strike is not possible, then the threat of a strike cannot perform its important functions.

Support for this proposition can be found in the experience of Montana and Ontario. In Montana, yet another illegal strike of jail guards occurred in 1979. However, the lower level of tension and violence in the post-strike period in Montana (in contrast to the New York strike) was primarily due to the legal nature of public employee strikes in that state (Zimmer and Jacobs 1981: 543). Ontario has reformed the Crown Employees Collective Bargaining Act (R.S.O. 1993), to provide for the right to strike after an essential services agreement is negotiated. In 1996 a legal strike of the Ontario Public Service did take place (including jails) under an essential services agreement. While the 1996 strike had some ugly

34. For a survey of significant works on this subject see County Sanitation v. Los Angeles County Employees (1985), 38 Cal. 3d., particularly at 574, fn. 18.

35. County Sanitation Dist. No. 2 v. Los Angeles County Employees' Assn. (1985), 38 Cal. 3d., 583. 
moments, essential and emergency services were maintained and the parties ultimately negotiated a settlement to the dispute.

Since legalizing the right to strike is not politically feasible in most North American jurisdictions, some adjustments to the collective bargaining system may still be made to minimize the negative impact of the nostrike law. In other words, it should be feasible as a policy matter to build into the law the possibility of strikes without explicitly sanctioning them.

\section{Scope of Bargaining}

A major contributing factor to the PATCO and jail guard strikes in New York state and Ontario appeared to be the narrow scope of bargaining. In Ontario it was the structure of bargaining and pensions, in New York state overcrowding and status, and for PATCO it was wages, pensions, and some working conditions. If these matters were negotiable, then conflict could be channelled to the bargaining table.

\section{The Role of Third Parties}

It is important that neutral third parties be given wide powers to intervene in such disputes. They should be trained in the special characteristics of these illegal strikes; where union objectives may be ill-defined; rank-and-file and leadership expectations diverge; and tension is at the point of boiling over. The normal no-strike law processes of fact-finding and arbitration may well be too slow and inadequate to handle the extreme conditions of the illegal strike. Legislation should be flexible enough to provide special mandatory mediation and cooling-off procedures at the earliest signs of an illegal strike. In Ontario, for example, prior to 1993 , mediation was available only on a voluntary basis under a system with compulsory arbitration as the only legal final step in collective bargaining. Although mediation was ultimately used in the 1979 jail guard strike, it might have been helpful if a trained public sector mediator were available earlier in the conflict.

\section{Information Gap}

It is more than a coincidence that both the Ontario and New York strikes were preceded by abnormally high grievance rates. ${ }^{36}$ Given the difficulty of ascertaining the depth of feeling of the jail guards, the parties (including mediators) ought to use these grievances as strike precursors. The grievances provide a safety valve for the release of tension, may contain valuable information about the workplace issues irritating the guards,

36. For example, Zimmer and Jacobs (1981: 536) found a doubling of fourth-step grievances by New York jail guards in the period 1976 to 1978; see also Hebdon (1992). 
and may serve as an early warning system for the ultimate explosion of conflict - the illegal strike.

\section{Future Research}

It is hoped that the framework developed in this paper will be applied to more cases of public sector illegal strikes. Also, since the model predicts that union leaders under no-strike laws will have difficulty obtaining the true preferences of their members in collective bargaining, a testable hypothesis is that these laws will generate greater instability (other factors equal) in union leadership. Finally, a logical extension of this paper would be the development of a trilateral theoretical model of public sector bargaining under no-strike laws. Such a model ought to take into account the unique features of public sector bargaining such as the political nature of the process.

\section{REFERENCES}

BECKER, Eugene H. 1982. "Analysis of Work Stoppages in the Federal Sector, 1962-81." Monthly Labor Review, Vol. 105, No. 8, 49-53.

CARD, David. 1990. "Strikes and Bargaining: A Survey of the Recent Empirical Literature." American Economic Association, Papers and Proceedings, May, 410-415.

CoOKE, S. T. 1983. "A Management View — The Canadian Postal System." IRRA 35th Annual Proceedings. Madison, Wisc.: IRRA, 94-101.

Coser, Lewis A. 1965. "Realistic and Nonrealistic Conflict." George Simmel. L. A. Coser, ed. New Jersey: Prentice-Hall.

Donovan, Ronald. 1990. Administering the Taylor Law: Public Employee Relations in New York. Ithaca: ILR Press.

EDWARDS, P. K. 1986. Conflict at Work. London, U.K.: Basil Blackwell.

FARBER, Henry S. and Harry C. KATZ. 1979. "Interest Arbitration, Outcomes, and the Incentive to Bargain." Industrial and Labor Relations Review, Vol. 33, No. 1, 55-63.

FinKLEMAN, Jacob. 1974. Employer-Employee Relations in the Public Service of Canada. Ottawa: Information Canada.

GODARD, John. 1992. "Strikes as Collective Voice: A Behavioral Analysis of Strike Activity." Industrial and Labor Relations Review, Vol. 46, No. 1, 161-175.

GoldenberG, Shirley B. 1983. "Strikes Against the Government: A Comparison of U.S. and Canadian Experience." IRRA 35th Annual Proceedings. Madison, Wisc.: IRRA, 86-93. 
GOLDENBERG, Shirley B. 1988. "Public-Sector Labour Relations in Canada." Public-Sector Bargaining, Second Edition. B. Aaron, J. M. Najita, and J. L. Stern, eds. Washington, D.C.: Bureau of National Affairs, 266-313.

GotBaum, Victor. 1972. "Collective Bargaining and the Union Leader." Public Workers and Public Unions. S. Zagoria, ed. Englewood Cliffs, N.J.: Prentice-Hall, 77-88.

GunderSON, Morley, John KERVIN, and Frank REID. 1983. "Strikes in Canada: Theories of Strike Determination and Strike Consequences." Centre for Industrial Relations, University of Toronto.

GUNDERSON, Morley. 1988. "Labour Economics and Industrial Relations." The State of the Art in Industrial Relations. G. Hébert, H. C. Jain, and N. M. Meltz, eds. Kingston, Ont.: Canadian Industrial Relations Association, 45-72.

GUNDERSON, Morley and Douglas HyaTT. 1996. "Canadian Public Sector Employment Relations in Transition." Public Sector Employment in a Time of Transition. D. Belman, M. Gunderson, and D. Hyatt, eds. Madison, Wisc.: Industrial Relations Research Association, 243-281.

HEBDON, Robert. 1992. "Industrial Conflict under Ontario's No-Strike Laws." Diss., University of Toronto, Centre for Industrial Relations.

HEBDON, Robert. 1996. "Public Sector Dispute Resolution in Transition." Public Sector Employment in a Time of Transition. D. Belman, M. Gunderson, and D. Hyatt, eds. Madison, Wisc.: Industrial Relations Research Association, 85-125.

HEBDON, Robert and Robert STERN. 1998. "Tradeoffs Among Expressions of Industrial Conflict: Public Sector Strike Bans and Grievance Arbitrations." Industrial and Labor Relations Review, Vol. 51, No. 2, 204221.

HURD, Richard W. and Jill K. KRIESKY. 1986. "Communications: The Rise and Demise of PATCO Reconstructed." Industrial and Labor Relations Review, Vol. 40, No. 1, 115-127.

JACOBS, James B. 1982. "The Role of Military Forces in Public Sector Labor Relations." Industrial and Labor Relations Review, Vol. 35, 377-393.

JAMIESON, Stuart M. 1968. Times of Trouble: Labour Unrest and Industrial Conflict in Canada, 1900-66, Report of the Task Force on Labour Relations, Study No. 22. Ottawa: Queen's Printer.

KERVIN, John. 1988. "Sociology, Psychology and Industrial Relations." The State of the Art in Industrial Relations. G. Hébert, H. C. Jain, and N. M. Meltz, eds. Kingston, Ont.: Canadian Industrial Relations Association, 187-242.

KATZ, Harry C. and Thomas A. KOCHAN.1992. An Introduction to Collective Bargaining and Industrial Relations. New York: McGraw Hill.

KEARNEY, Richard C. 1992. Labor Relations in the Public Sector. New York: Marcel Dekker. 
KHEEL, Theodore. 1969. "Strikes and Public Employment." Michigan Law Review, Vol. 67, 931.

KOCHAN, Thomas A. 1974. "A Theory of Multilateral Collective Bargaining in City Governments." Industrial and Labor Relations Review, Vol. 27, No. 4, 525-542.

Lund, John and Cheryl MARANTO. 1996. "Public Sector Labor Law: An Update." Public Sector Employment in a Time of Transition. D. Belman, M. Gunderson, and D. Hyatt, eds. Ithaca, N.Y.: Industrial Relations Research Association, 21-39.

MELTZER, Bernard D. and Cass R. Sunstein. 1983. "Public Employee Strikes, Executive Discretion, and the Air Traffic Controllers." University of Chicago Law Review, Vol. 50, 731-799.

MCGuiRE, J. Powers. 1987. "A Comparison of the Right of Public Employees to Strike in the United States and Canada." Labor Law Journal, May, 304-310.

NORTHRUP, Herbert R. 1984. "The Rise and Demise of PATCO." Industrial and Labor Relations Review, Vol. 37, No. 2, 167-184.

NORTHRUP, Herbert R. 1986. "Reply."Industrial and Labor Relations Review, Vol. 40, No. 1, 115-127.

PETERSON, Andrew A. 1981. "Deterring Strikes by Public Employees: New York's Two-for-One Salary Penalty and the 1979 Prison Guard Strike." Industrial and Labor Relations Review, Vol. 34, No. 4, 545-562.

SAPSFORD, David and Peter TURnBull. 1994. "Strikes and Industrial Conflict in Britain's Docks: Balloons or Icebergs?" Oxford Bulletin of Economics and Statistics, Vol. 56, No. 3, 249-265.

SCHNEIDER, B. V. H. 1988. "Public-Sector Labor Legislation -- An Evolutionary Analysis." Public-Sector Bargaining. 2nd ed. J. M. Najita and J. L. Stern, eds. Washington, D.C.: Bureau of National Affairs.

SHANNON, Steven C. 1978. "Work Stoppage in Government: The Postal Strike of 1970." Monthly Labor Review, July, 14-22.

SOMBRETTO, Vincent R. 1983. "Strikes Against the Government: A Union View of the Problem." IRRA 35th Annual Proceedings, Madison, Wisc.: IRRA, 114-118.

STERN, James L. and Craig OLSON. 1982. "The Propensity to Strike of Local Government Employees." Journal of Collective Negotiations in the Public Sector, Vol. 11, No. 3, 201-214.

STERRET, Grace and Antone ABOUd. 1982. The Right to Strike in Public Employment. Ithaca, N.Y.: ILR Press.

STEVEnS, Carl M. 1966. "Is Compulsory Arbitration Compatible with Bargaining." Industrial Relations, Vol. 5, No. 1, 38-52.

SuMMERS, Clyde. 1991. "Patterns of Dispute Resolution: Lessons from Four Countries." Comparative Labor Law Journal, Vol. 12, No. 1, 165-177. 
SWAN, Kenneth P. 1985. "Differences Among Provinces in Public Sector Dispute Resolution." Public Sector Compensation. D. W. Conklin, T. J. Courchene, and W. A. Jones, eds. Toronto: Ontario Economic Council.

SWIMMER, Gene and Allan MACDONALD. 1985. "Dispute Resolution in the Ontario Public Sector: What's So Wrong With the Right to Strike?" Public Sector Compensation. D. W. Conklin, T. J. Courchene, and W. A. Jones, eds. Toronto: Ontario Economic Council.

Swimmer, Gene. 1989. "Critical Issues in Public Sector Industrial Relations." Collective Bargaining in Canada. A. S. Sethi, ed. Scarborough, Ont.: Nelson, 408.

WALTON, Richard E. and Robert B. MCKERSIE. 1965. A Behavioral Theory of Negotiations. New York: McGraw-Hill.

WhEELER, Hoyt N. 1985. Industrial Conflict: An Integrative Theory. Columbia, S.C.: University of South Carolina Press.

WHITE, Jerry P. 1990. Hospital Strike. Toronto: Thompson Educational.

WoODS, H. D., Chairman. 1968. Canadian Industrial Relations: Report of the Task Force on Labour Relations. Ottawa: Queen's Printer.

ZIMMER, Lynn and James B. JACOBS. 1981. "Challenging the Taylor Law: Prison Guards on Strike." Industrial and Labor Relations Review, Vol. 34, No. 4, 531-544.

\section{RÉSUMÉ}

Déterminants behavioraux des grèves illégales dans le secteur public

Cet article analyse certaines caractéristiques behaviorales des grèves illégales dans le secteur public en Amérique du Nord. Ces grèves tirent leur importance de leur nombre, de leurs effets négatifs souvent dévastateurs et de la disfonction qu'elles représentent par rapport au mandat politique d'éviter les grèves - un objectif central de plusieurs systèmes de relations du travail dans le secteur public.

Ces grèves peuvent attirer l'attention au plan national en s'attaquant à des services vitaux menaçant ainsi la santé et la sécurité du public. Elles peuvent alors appeler des interventions extraordinaires de la part des gouvernements : par exemple, il y eut 45 cas aux États-Unis entre 1970 et 1981 où l'armée a remplacé des grévistes du secteur public (Jacobs 1982).

Notre cadre d'analyse théorique de ces grèves vise à expliquer la spontanéité de telles grèves, les caractéristiques des syndiqués et la 
carence correspondante de contrôle syndical, la présence de conflits sans objectifs syndicaux clairs et le processus du règlement des conflits par des agences neutres. Il y a plusieurs conséquences sérieuses non voulues à un régime de négociation collective sans droit de grève : cela peut empêcher l'ajustement des attentes nécessaire au compromis, nuire à la divulgation d'informations précieuses sur les préférences des parties, conduire à des explosions de pression et être plus difficile à réguler vu le manque d'objectifs clairement définis.

Un examen de deux grèves de gardiens de prison en Ontario illustre ces faiblesses. Par exemple, l'arbitrage de différends, même en arrivant au même résultat ne peut pas remplacer le processus d'ajustement des attentes des parties si nécessaire au compromis dans les systèmes avec droit de grève. Comme tels alors, les lois bannissant le droit de grève produisent des formes moins participatives de représentation collective surtout en cas d'impasse pendant la négociation.

L'analyse suggère trois implications pour les politiques publiques :

Champ de négociation. Il semble qu'un aspect positif des grèves de PATCO et des gardiens de prisons dans l'État de New York et en Ontario fut le champ étroit de négociation. En Ontario, ce fut la structure de négociation et les pensions, dans l'État de New York, la surpopulation et le statut et pour PATCO, les salaires, les pensions et quelques conditions de travail. Si ces sujets étaient négociables, les conflits pourraient alors être canalisés à la table de négociation.

Le rôle des tiers. Il est important de donner aux tiers intervenant dans de tels conflits de larges pouvoirs. Ils devraient être au fait des caractéristiques particulières des grèves illégales, être capables d'identifier des objectifs syndicaux mal définis, de voir des divergences d'attentes entre les membres et leurs dirigeants et de reconnaître ce moment où la tension est au maximum. Le processus normal et habituel de recherche des faits et d'arbitrage peut très bien être trop lent et trop lourd pour les conditions extrêmes d'une grève illégale. La loi devrait être suffisamment flexible pour permettre une médiation spéciale obligatoire et des procédures de trêve dès les premiers signes d'une grève illégale. En Ontario, par exemple, avant 1993, la médiation n'était disponible que sur une base volontaire dans un système où l'arbitrage obligatoire était la seule étape finale légale à la négociation collective. Même si, finalement, la médiation fut utilisée lors de la grève des gardiens de prison en 1979, cela aurait été utile si un médiateur était intervenu plus tôt dans le conflit.

Le problème de l'information. C'est plus qu'une coïncidence si les grèves de l'Ontario et de New York furent précédées d'un taux anormalement élevé de griefs. Vu la difficulté d'évaluer la nature des sentiments 
des gardiens de prison, les parties, incluant les médiateurs, auraient dû utiliser ces griefs comme indices précurseurs de grève. De tels griefs constituent une valve de sécurité pour la tension, contiennent une information utile sur les irritants et peuvent servir de préavis pour cette ultime explosion de conflit que constitue une grève illégale.

\section{RESÚMEN}

Determinantes del comportamiento en las huelgas ilegales del sector publico : Casos en los Estados Unidos y Canadá

Este articulo desarrolla un marco para el análisis de las huelgas ilegales del sector publico que explica el comportamiento observado por la parte de los empleados, los sindicatos, los administradores y otras partes en el conflicto. Se ha encontrado que las leyes que imposibilitan el derecho de huelga, van en deterioro de las ventajas de la negociación obligatoria como sistema de gestión de las relaciones laborales. Una nueva guía teórica ayuda a comprender y explicar las características de las huelgas ilegales tales como la velocidad del desarrollo, el movimiento organizado y uniforme de los empleados, la falta de control por parte de los sindicatos, el confrontamiento sin objetivos sindicales claros y la desintegración de los mecanismos de regulación del proceso por parte de agencias neutrales. Tres sujetos de política sobresalen: Algunos de los conflictos pudieran haber sido evitados con una ampliación de los mandatos de la negociación colectiva (PATCO y los guardias de prisiones en Ontario); arbitraje e intervención de terceras partes en la solución de conflictos debería ser obligatoria mediante legislación ; y información concerniente a la problemática de los empleados deberá ser puesta a la disposición de las instancias de arbitraje antes de que el conflicto degenere fuera de control. 